\title{
Analysis of fracture processes in reinforced concrete beams without stirrups
}

\author{
M. Słowik \\ Lublin University of Technology, Poland \\ m.slowik@pollub.pl, bttp://orcid.org/0000-0001-9627-3625
}

\begin{abstract}
The analysis of fracture processes which led to shear failure in reinforced concrete beams without transverse reinforcement was performed on the basis of test results from the author's own experimental investigation and numerical simulations. The variable parameters during the experiment were a beam's length and a shear span. It was observed that the character of failure in the beams depended on the beam's length and the span-to-depth ratio. In slender beams characterized by the shear span-to-depth ratio 3.4 and 4.1, the formation of the critical diagonal crack caused a brittle, sudden failure and the shear capacity was low. In short beams, when the shear span-to-depth ratio was 1.8 and 2.3 , the failure process had a more stable character with a slow developing of inclined cracks and the significantly higher load capacity was reached. The activation of various shear transfer mechanisms was examined with regard to the slenderness of the member and the transition between a beam action which took place in slender beams to an arch action which predominated in short beams was described.
\end{abstract}

KEYwORDS. Fracture process; Reinforced concrete; Shear failure.

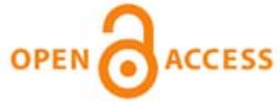

Citation: Słowik M., Analysis of fracture processes in reinforced concrete beams without stirrups, Frattura ed Integrità Strutturale, 57 (2021) 321-330.

Received: 14.04.2021

Accepted: 14.06 .2021

Published: 01.07.2021

Copyright: (C) 2021 This is an open access article under the terms of the CC-BY 4.0, which permits unrestricted use, distribution, and reproduction in any medium, provided the original author and source are credited.

\section{INTRODUCTION}

$\mathrm{S}$ everal scientific works on shear capacity of structural concrete members were conducted all around the world. The shear transfer model for reinforced concrete members with transverse reinforcement is well recognized for static loading and some new researches are carried out according to impact loading, for instance [1]. Nevertheless, there is still no consensus on the general theory for a rational shear design of reinforced concrete members without transverse reinforcement although numerous experimental investigations have been dedicated to beams without stirrups. One of the first broad-scale test results were reported in the middle of the $20^{\text {th }}$ century by Leonhardt and Walther [2], and Kani [3]. Then experiments were being continued and an effort was being undertook to improve the understanding of a load transfer in reinforced concrete members due to shear forces, for example [4-10]. Despite these works, the shear capacity for members without transverse reinforcement is often calculated on the basis of empirical formulas (for example like in the European recommendation Eurocode 2 [11] and the American standard ACI 318 [12]). However, empirical formulas 
can bring some doubts connecting with unsafe estimates for the structural members which are outside of empirical calibration. Therefore, the problem of shear capacity of members without transverse reinforcement is still attracted the interest of many researchers. Several works have been published recently, for instance [13-17]. The growing knowledge of shear behaviour in beams without stirrups brought the grounds for developing mechanical models of shear transfer mechanisms. Particularly, two theories, e.g. the Modified Compression Field Theory [18] and the Critical Shear Crack Theory [19], helped to work out the shear design concepts which were put into practice, for instance in the latest recommendation of International Federation for Structural Concrete - fib Model Code 2010 [20] and in a few national codes [21, 22]. It must be emphasized that these new design methods are dedicated to predict the shear capacity of typical slender beams.

There are several potential shear transfer actions recognized by the researchers. Because the shear failure is affected by various factors, a theoretical description of shear transfer mechanisms is very complicated. The important parameter which influences the failure process in the beams is the ratio of longitudinal reinforcement. The influence of the longitudinal reinforcement ratio on the character of failure in flexural members has been analyzed in depth in [17]. Slightly reinforced concrete beams fail soon after appearing of a few flexural cracks and the failure process has a brittle character. In moderately reinforced concrete beams, a stable growth of several flexural cracks is usually observed and the full flexural capacity is reached. In higher reinforced concrete beams, the shear failure predominates due to shear forces and the propagation of inclined cracks. The shear failure often causes dangerous, brittle damage. However, the stable process of developing inclined cracks can also be observed and a relatively high shear capacity can be obtained in some kind of higher reinforced concrete beams [24].

The experimental results of shear capacity in reinforced concrete beams presented in professional literature show a big scatter. The question arises as to whether the shear capacity depends on the beam's length and as to what contribution of the longitudinal reinforcement in the shear transfer is. When analyzing shear behaviour of longitudinally reinforced concrete beams without transverse reinforcement not only shear capacity should be of interest but also the progress of failure process should be examined. The development of cracks, the propagation of a critical crack and the stress distribution are of primary importance. Therefore, the author's own experimental investigation was performed to analyze the failure process in longitudinally reinforced concrete beams. The experiment was focused on the observation of the cracks formation and propagation in the beams of a higher reinforcement ratio. Variable length of the beams and the arrangement of loading allowed to research into the effect of the beam's span and the shear span-to-depth ratio on the load capacity and the fracture process in reinforced concrete beams without transverse reinforcement.

\section{EXPERIMENTAL INVESTIGATION}

7 he experimental investigation was performed on four beams: two slender beams: OI-1, OI-2 and two short beams: PI-1, PI-2. The beams had a rectangular cross-section of the width $b=0.12 \mathrm{~m}$, the total height $b=0.25 \mathrm{~m}$ and the effective depth (depth measured from the compression edge to the level of longitudinal steel bars) $d=0.22 \mathrm{~m}$. Two deformed steel bars of the diameter $18 \mathrm{~mm}$ were used as longitudinal reinforcement in the beams. The reinforcing steel was of RB500 category and it was characterized by the yield stress $f_{y}=545 \mathrm{MPa}$ and the tensile strength $f_{t}=631 \mathrm{MPa}$. The ratio of longitudinal reinforcement was $\rho=1.8 \%$. Transverse reinforcement was not used in the beams. The cross section of the beams is shown in Fig. 1.

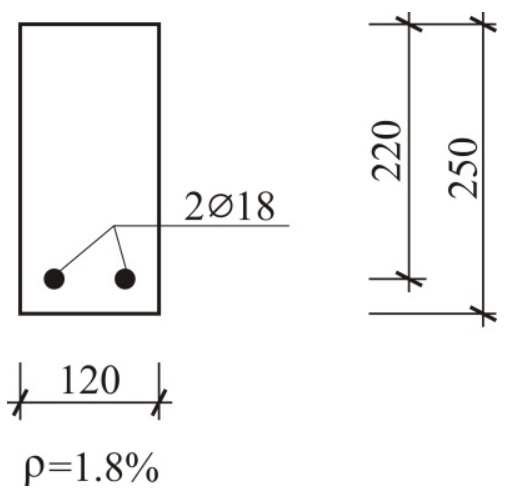

Figure 1: Cross section of the beams. 
The beams had a different total length and span (distance between the supports) during the test. The span for two slender beams OI-1 and OI-2 was the same $l_{\text {eff }}=1.8 \mathrm{~m}$ whereas the span in short beams differed and it was $l_{\text {eff }}=1.0 \mathrm{~m}$ in the beam PI-2 and $l_{\text {eff }}=0.8 \mathrm{~m}$ in the beam PI-1.

The beams were simply supported during the test. The external force was applied from the testing machine in the middle of the span when testing three beams OI-1, PI-2, PI-1 and in case of the beam OI-2 the applied force was symmetrically distributed into two forces, as it is presented in Fig. 2. A different scheme of load applying in the beam OI2 (two forces) compering to a load arrangement in rest of beams (one force) was used in order to obtain a different shear span $a$ (distance between the applied force and the support) in slender beams. Such arrangement of loading caused that the shear span during the test was also a changing parameter and the beams were characterized by a different shear span-to-depth ratio $a / d$ (see Tab. 1).
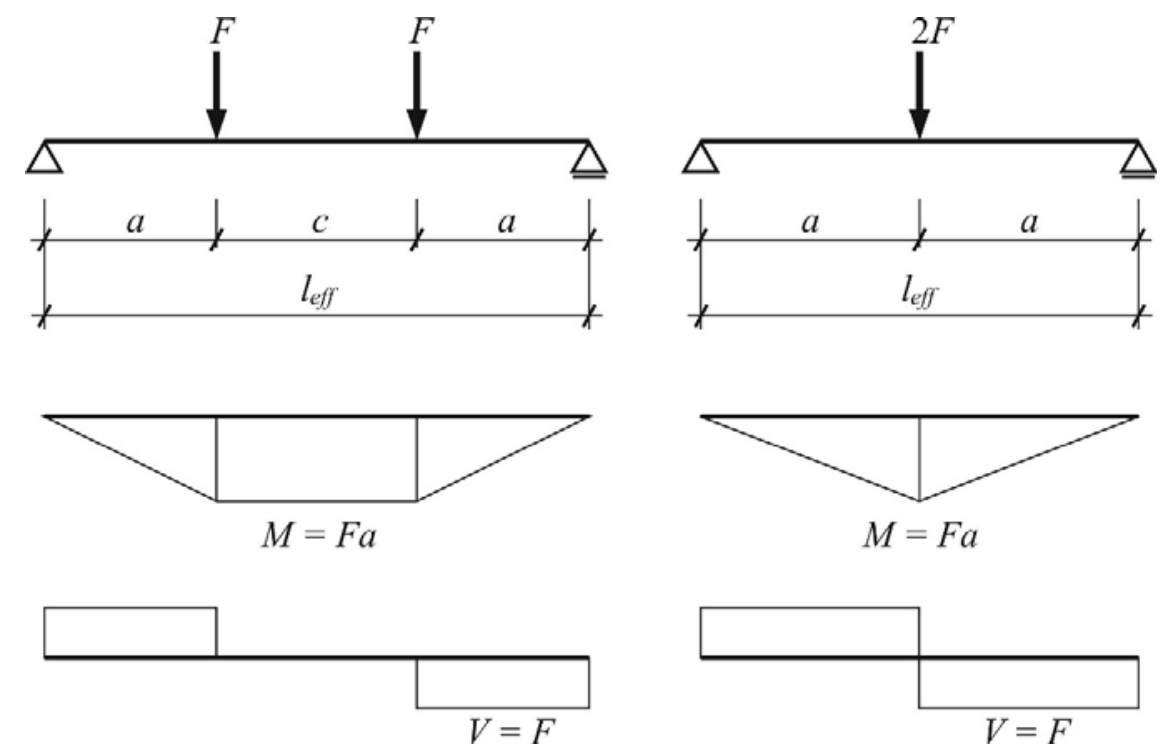

Figure 2: Static scheme of tested beams.

\begin{tabular}{cccc}
\hline Beam & Span, $l_{\text {eff }}[\mathrm{m}]$ & Shear span, $a[\mathrm{~m}]$ & $\begin{array}{c}\text { Shear span-to-depth } \\
\text { ratio, } a / d[-]\end{array}$ \\
OI-1 & 1.8 & 0.90 & 4.1 \\
OI-2 & 1.8 & 0.75 & 3.4 \\
PI-2 & 1.0 & 0.50 & 2.3 \\
PI-1 & 0.8 & 0.40 & 1.8 \\
\hline
\end{tabular}

Table 1: Tested members.

The beams were made by the same constructional concrete. The dolomite aggregate of the maximum size 16 mm was used to produce the concrete mixture. Concrete properties were tested on standardized specimens and at standard conditions. The compressive strength of concrete and the modulus of elasticity were measured on cylindrical specimens $\phi 150 / 300 \mathrm{~mm}$ whereas the tensile strength of concrete was tested using the splitting test on cubic specimens 150/150/150 mm. The obtained results are presented in Tab. 2. The uniaxial tensile strength of concrete was calculated on the basis of the splitting tensile strength as it is recommended in Eurocode 2 [10]: $f_{c t}=0.9 f_{c t, s p}=3.15 \mathrm{MPa}$.

\begin{tabular}{ccccc}
\hline Property & $\begin{array}{c}\text { Number of specimens, } \\
{[-]}\end{array}$ & $\begin{array}{c}\text { Mean value, } \\
{[\mathrm{MPa}]}\end{array}$ & $\begin{array}{c}\text { Standard deviation, } \\
{[\mathrm{MPa}]}\end{array}$ & $\begin{array}{c}\text { Coefficient of } \\
\text { variation, }[\%]\end{array}$ \\
Compressive strength $f_{c}$ & 27 & 35 & 5.6 & 16 \\
Tensile splitting strength $f_{c, s, p}$ & 32 & 3.5 & 0.4 & 11 \\
Modulus of elasticity $E_{c}$ & 19 & 41400 & 93650 & 9 \\
\hline
\end{tabular}

Table 2: Concrete properties. 
The beams were loaded up to failure. The applied load increased gradually and the cracks' appearing and developing were monitored, and the cracks' widths were measured in the following steps of loading. The bond between steel bars and concrete was monitored during the test. For this purpose, steel bars were lengthened out of the beam and dial test gaudes were placed on the ends of bars having the contact with the beam's edge. The slip of steel bars was not observed during the experiment what confirmed that steel bars were correctly bonded and an un-anchor failure had no place. The instrumentation for bond checking is presented in Fig. 3.

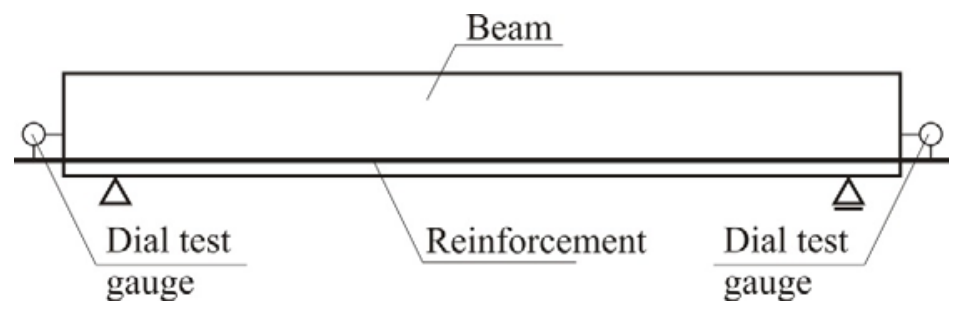

Figure 3: Bond checking.

All beams failed due to the propagation of inclined cracks and the shear governed the failure. The load applied on the beams at the failure was read from the testing machine $P_{u l t}$ and the ultimate shear force $V_{u l t}$ was calculated according to the schemes presented in Fig. $2(P=2 F)$. The ultimate loads $P_{u l t}$ and ultimate shear forces $V_{u l t}$ of tested beams are presented in Tab. 3. A significantly lower shear capacity $V_{\text {ult }}$ were observed in longer beams characterized by the shear span-to-depth ratio 4.1 and 3.4 comparing to the shear forces at failure in short beams, in which $a / d$ was 2.3 and 1.8 . The obtained results were juxtaposed with some test results reported by Kani [2]. Although both experiments were performed in similar conditions, the shear forces at failure could not be compared directly because the dimensions of the beams tested by Kani and the dimensions of the beams from the own test differed a little. Therefore, the relationships of the ultimate shear stress $v_{u l t}=V_{\text {ult }} /(b d)$ versus the shear span-to-depth ratio $a / d$ were confronted. The comparison which is demonstrated in Fig. 4 revealed satisfactory agreement of test results.

\begin{tabular}{|c|c|c|c|c|}
\hline Beam & $\begin{array}{l}\text { Shear span-to-depth } \\
\quad \text { ratio, } a / d[-]\end{array}$ & $\begin{array}{l}\text { Applied load, } \\
P_{u l t}[\mathrm{kN}]\end{array}$ & $\begin{array}{c}\text { Shear capacity, } \\
V_{u l t}[\mathrm{kN}]\end{array}$ & $\begin{array}{l}\text { Ultimate shear stress, } \\
v_{\text {ult }}=V_{\text {ult }} /(b d)[\mathrm{MPa}]\end{array}$ \\
\hline Slender beam OI-1 & 4.1 & 90.0 & 45.0 & 1.50 \\
\hline Slender beam OI-2 & 3.4 & 87.0 & 43.5 & 1.45 \\
\hline Short beam PI-2 & 2.3 & 142.0 & 71.0 & 2.34 \\
\hline Short beam PI-1 & 1.8 & 180.0 & 90.0 & 3.00 \\
\hline
\end{tabular}

Table 3: Shear capacity of the beams.

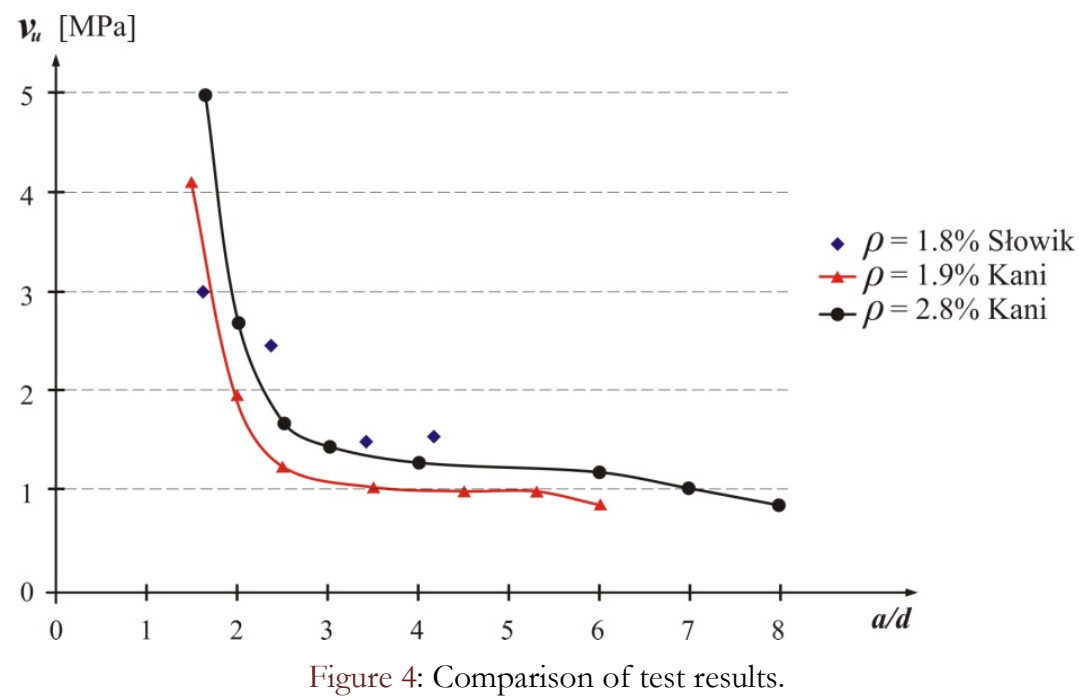


When analyzing test results presented in Fig. 4 it was concluded that the shear span-to depth ratio had a considerable influence on the ultimate shear stress of reinforced concrete beams without transverse reinforcement. It was observed that the decrease in the shear span-to-depth ratio resulted in the increase in the ultimate shear stress and this tendency appeared to be more significant when $a / d<2.5$. When the shear span to-depth ratio was $a / d \geq 2.5$ (such $a / d$ is typical for slender beams) the shear capacity was relatively low whereas when the shear span-to-depth ratio did not exceed 2.5 (such a/d characterizes short beams) the shear capacity was noticeable higher. In order to explain a significantly higher load capacity obtained in short beams comparing to shear capacity in slender beams, the analysis of failure process in the beams according to the beams' span and the shear span-to-depth ratio was performed.

\section{ANALYSIS OF CRACK PROPAGATION AND TYPE OF FAILURE}

$\mathrm{W}$ hen monitoring the cracks appearance and development in tested beams as well as analyzing crack widths, several observations were made. Flexural cracks appeared as first in all beams. Due to a relatively high ratio of longitudinal reinforcement, the steel bars provided considerable resistance to the opening of the flexural cracks in the region of the maximum bending moment. Therefore, several flexural cracks developed and the number of flexural cracks depended on the beams' length. With the increase of the beam's length the number of flexural cracks increased and the flexural cracks propagated deeper towards the compression edge of the beam. As the longitudinal reinforcement stabilized the propagation of flexural cracks, with the further load increase diagonal cracks started to form in the support regions. The inclination of cracks was associated with the trajectories of principal stress due to the shear force and the bending moment acting simultaneously in cross sections, see Fig. 5.

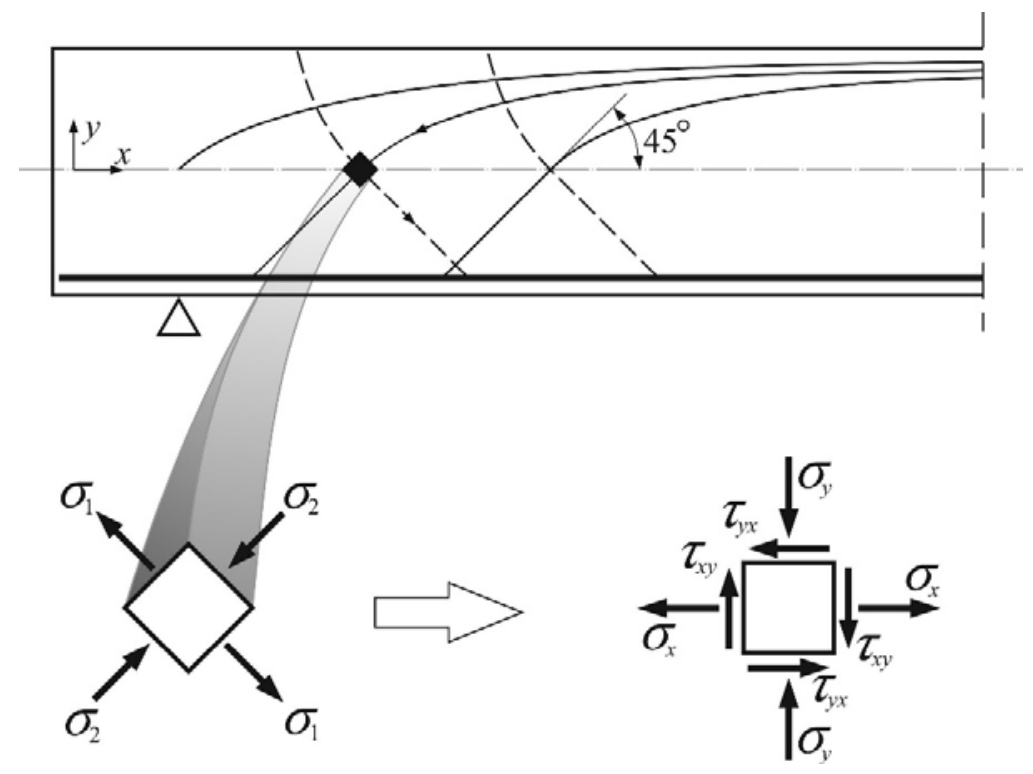

Figure 5: Trajectories of principal stress.

The inclinations and widths of diagonal cracks as well as the development of the critical crack were influenced by the shear span-to-depth ratio. In slender beams OI-1 and OI-2 (characterized by the shear span-to-depth ratio 4.1 and 3.4) the critical diagonal crack formed in one side of the beam, in the middle of the support zone. Shear failure in slender beams was caused by the critical crack growth which developed from the flexural-shear crack. In the region where the longitudinal reinforcement could not control the propagation of the inclined shear crack, the crack turned out to be unstable. It led to the brittle collapse of the member.

A different shear-transfer action was observed in short beams PI-2 and PI-1 (characterized by the shear span-to-depth ratio 2.3 and 1.8) in which the load was applied at a short distance to the supports. Two main inclined cracks propagated in the direction between the load application point and the supports The development of cracks had a stable character and finally one of the inclined cracks predominated and provoked the failure of the beam.

Fig. 6. illustrates the crack patterns and the failure crack in the beams. It should be pointed that in all tested beams the failure was connected with the propagation of the inclined crack. 

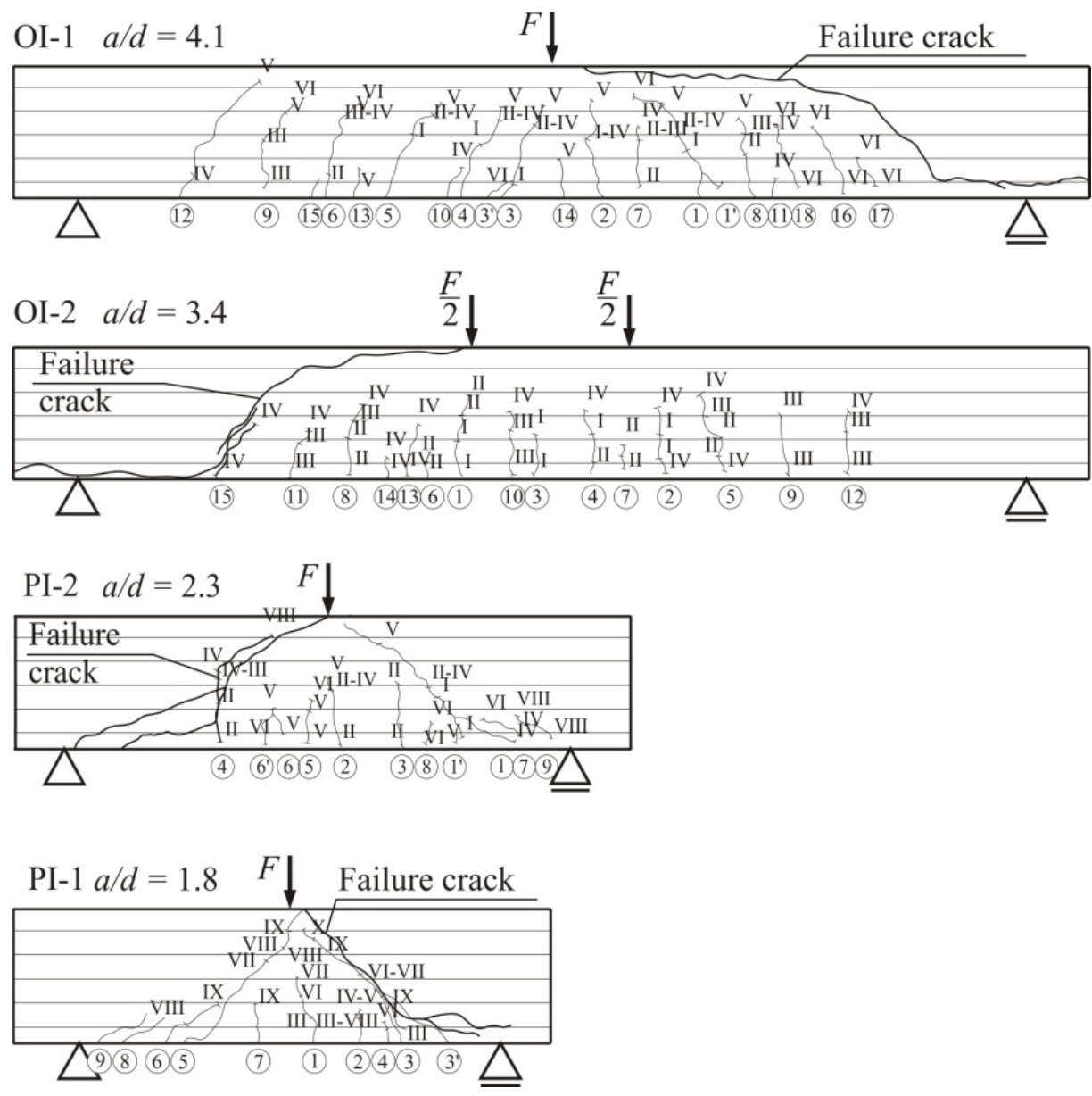

Figure 6: Crack patterns in the beams.

The results of the performed experimental investigation showed that considerable differences existed between short and slender beams not only according to the shear capacity but also to the development of cracks and the character of failure. Therefore, the analysis of shear behaviour should not be limited to determine the shear capacity in a critical cross section but different shear transfer actions in the support zone of the beams should be widely examined.

\section{SHEAR TRANSFER ACTIONS}

7 he main mechanisms of shear stress transfer in typical slender beams without shear reinforcement which were recognized up till now are as following: shear transfer in the compression zone, residual tensile stress in the fracture process zone (strain softening effect), aggregate interlock and dowel action of reinforcing bars. They are demonstrated in Fig. 7. The distribution of residual stress in tensile concrete in front of the crack was described in [24]. The analysis presented in [17], has confirmed that the strain softening of concrete in tension has the most important contribution in the crack initiation in case of flexural cracks. The empirical model for estimating dowel action was proposed in [4]. Several models for describing the effect of aggregate interlock were developed, among them well known model derived by Walraven [25] and new propositions presented recently in [26, 27]. However, the activation of the individual shear transfer mechanism seems to be depended on the width of the inclined crack.

In case of slender beams a brittle failure was observed and the quick development of the first diagonal crack followed to the beam collapse. The maximum crack width before failure did not exceed $0.1 \mathrm{~mm}$. The shear transfer mechanisms: strain softening effect, aggregate interlock and dowel action of steel bars occurred during the diagonal crack formation but the contribution of the aggregate interlock on the shear transfer seemed to be the most important. 


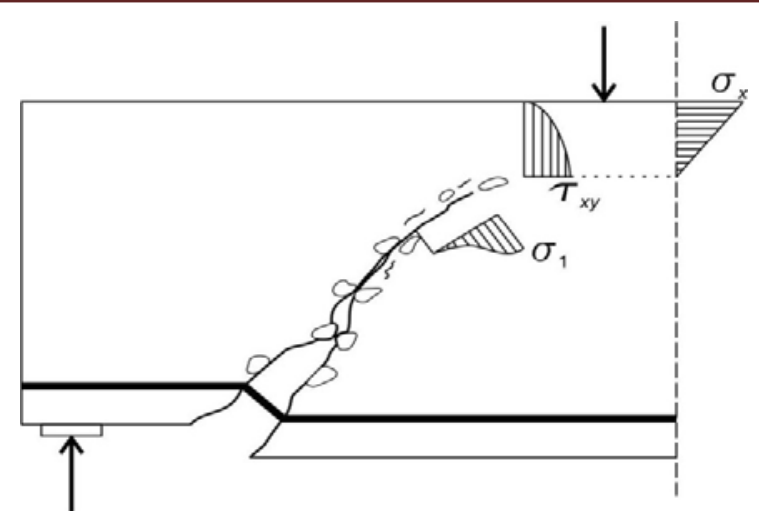

Figure 7: Shear mechanisms in slender beams.

In case of short beams the influence of the aggregate interlock on the shear transfer was not predominant. The maximum measured crack width before failure reached $0.7 \mathrm{~mm}$. The large opening of the critical diagonal crack reduced the interlock of aggregate particles. The direction of inclined cracks suggested that the main stream of stress transfer ran from the applied load directly to the supports, as it is demonstrated in Fig. 8. It gave the evidence that an arch action appeared and the longitudinal steel bars, acting as a tensile tie, had an important influence on the shear resistance.

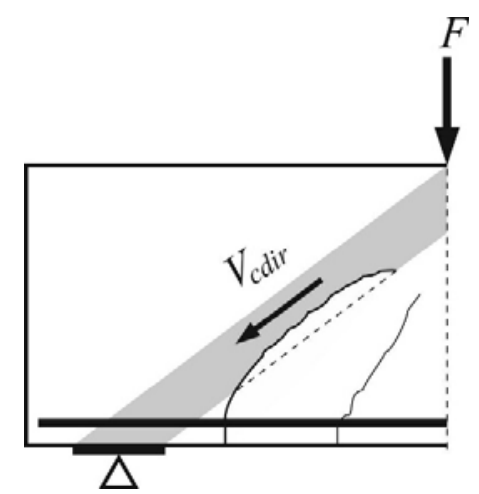

Figure 8: Shear failure mechanisms in short beams.

In order to look deeper into the phenomenon governing cracks distribution in the investigated beams, a numerical simulation was performed. The numerical calculations were provided using the finite element program ANSYS. Two beams were modelled: the short beam which corresponded to the tested member PI-1 of $a / d=1.8$ and the longer beam of $a / d=2.5$ because the shear span to depth ratio 2.5 has been found to be critical one which separates beams for slender and short. Eight-node solid elements were used to model the concrete and three-dimensional bar elements were taken from the library of the ANSYS program for modelling steel bars. The discrete model of reinforcement was applied and the bond between concrete and steel was modelled as the identical displacement of connected nodes. The nonlinear characteristic of concrete, in particular the strain softening of tensile concrete, was taken into account. A three dimensional stress-strain state was considered by using the Willam-Warnke limit surface. The Newton-Raphson method of solving the finite element system of equations was used. The detailed description of the procedure applied to the finite element simulation was presented in [28]. As the results of the numerical calculations, trajectories of total strain were generated. In Fig. 9 the obtained distributions of total strain are presented for both beams examined in case of two loading levels: the load level which correspond to the formation of the first diagonal crack $(V=30 \mathrm{kN})$ and the load level before failure.

The significant differences can be observed when comparing the obtained numerical results for both beams. In case of the short beam $(a / d=1.8)$, two inclined struts transferring the load directly to the supports were generated. The strain concentration in the narrow struts was clearly observed in the load level before failure but the tendency of the struts formation was seen also in the load level $\mathrm{V}=30 \mathrm{kN}$ connecting with the formation of diagonal cracks. This finding brought the evidence that the arch action took place in the short beam. Quite different progress of strain distribution was observed in the longer beam $a / d=2.5$. The streams of total strain pointed that, before the formation of diagonal cracks, 
several flexural cracks were able to develop in the mid-span of the beam, in the region where bending moment predominated. Then, the stronger concentration of strain in the support zone suggested the failure which was connected with the formation of the critical diagonal crack. Such development of strains confirmed that the beam action predominated in the beam of $a / d=2.5$.

The total strain distributions presented in Fig. 9 showed a reasonable agreement with the experimental observation of crack patterns. The obtained numerical results have confirmed that the different work action can be observed in longitudinally reinforced concrete beams in dependence of the member's length. Finally, it can be recapitulated that the higher shear capacity of short beams can be explained by the transfer from the beam action in slender beams to the arch action in short beams. Therefore, the adequate shear models should be consider in reinforced concrete beams without transverse reinforcement according to their length. Design methods do predict the shear capacity which are used for slender beams are not suitable for short beams.

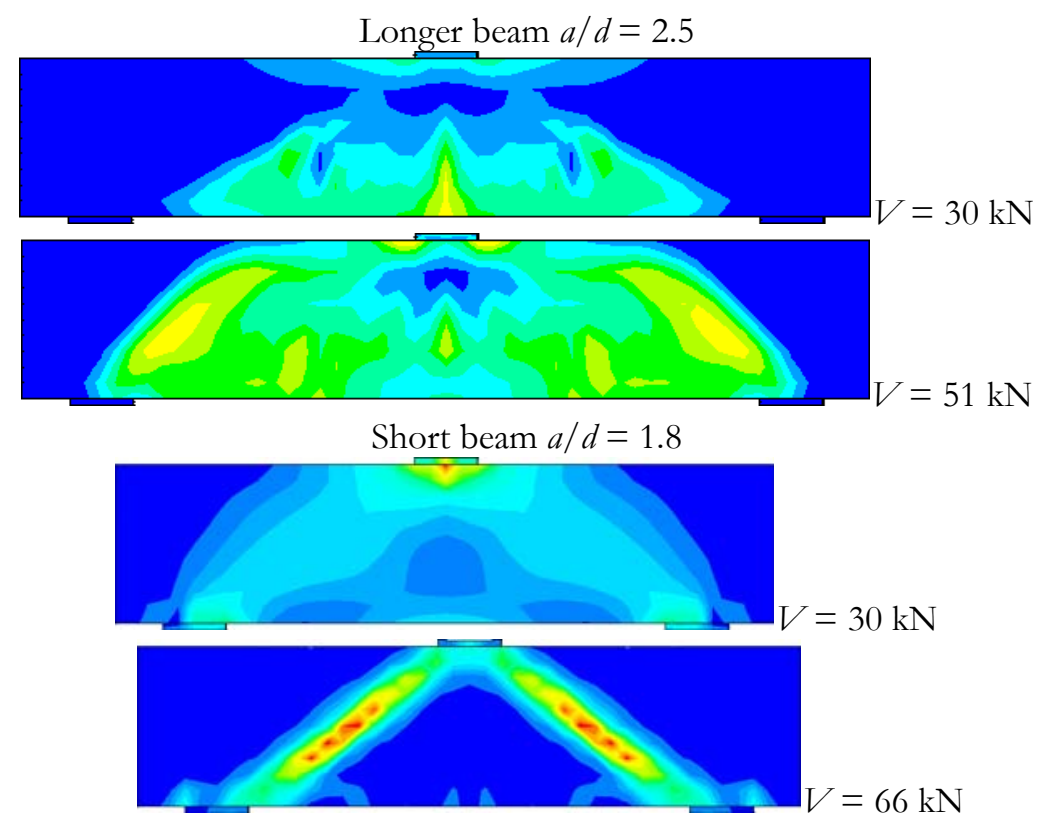

Figure 9: Total strain distribution - FEM results.

\section{CONCLUSIONS}

$\mathrm{B}$ ased on the performed analysis of cracking process and the character of failure in longitudinally reinforced concrete beams without transverse reinforcement, the following conclusions can be drown:

1. The significant influence of the beam's length and the shear span-to-depth ratio on the shear capacity and the character of failure is observed in reinforced concrete beams without transverse reinforcement.

2. Different character of failure is noticed in short beams comparing to typical slender beams. In slender beams a brittle shear failure is caused by a sudden development of the first diagonal crack. The load capacity is low and it depends on the shear force which causes diagonal cracking. In short beams a more stable growth of two inclined cracks is observed and a significantly higher load capacity is reached.

3. The fracture process in the beams changes also according to the shear span-to-depth ratio $a / d$. In the beams characterized by $a / d \geq 2.5$, the beam shear-transfer action takes place whereas in the beams of $a / d<2.5$ the arching action predominates. The transfer from the beam action to the arch action is the main factor which causes a different character of fracture process in reinforced concrete beams without transverse reinforcement.

The special fib report [29] was dedicated to shear in structural concrete in 2018, where in the concluding remarks [30] it has been pointed that: “... The hypotheses underlying existing models for the shear behavior of structural concrete are mainly based on interpreted (rather than measured) data from experiments that are not representative of real-lifestructures. Hence, the existing models are biased and may not capture the real mechanical behaviour. Consequently, no general accepted theory, in particular for members with very little or no stirrup reinforcement, is available today. However, 
such a theory is essential, in particular to avoid unnecessary strengthening of countless existing infrastructure objects that are "structurally deficient" according to current codes. ...".

The performed experiments presented in the paper provide more insight in recognizing the failure processes in reinforced concrete members without shear reinforcement of different length. Taking into account the obtained results it can be concluded that failure and load carrying capacity in slender beams and short beams should be analyzed separately. The design methods to predict the shear capacity of reinforced concrete members without transverse reinforcement should rely on a comprehensive understanding of failure processes which are connected with different shear transfer mechanisms in short beams comparing to mechanisms observed in typical slender beams.

\section{ACKNOWLEDGMENTS}

his work was supported by Lublin University of Technology.

\section{REFERENCES}

[1] Oliviera M. C., da Cunha Teles D. V., de Figueiredo Amorin D. L. N. (2020). Shear behaviour of reinforced concrete beams under impact loads by the Lumped Damage framework. Frattura ed Integrità Strutturale, 53, pp. 13-25. DOI: 10.3221/IGF-ESIS.53.02.

[2] Leonhardt F., Walther R. (1962). Beiträge zur Behanndlung der Schubprobleme im Stahlbetonbau. In: Schubversuche an einfeldrigen Stahlbetonbalken mit und ohne Schubbewehrung, Deutscher Ausschuss für Stahlbeton, Berlin, Heft 151.

[3] Kani G.N.J. (1966). Basic Facts Concerning Shear Failure. Journal of the American Concrete Institute, June, pp. 675692.

[4] Baumann T., Rüsch H. (1970). Versuche zum Studium der Verdubelungswirkung der Biegezugbewehrung eines Stahlbetonbalken. Deutscher Ausschuss für Stahlbeton, no. 210, Ernst \& Sohn, Berlin, pp. 43-83.

[5] Jelić I., Pavlović M.N., Kotsovos M.D. (1999). A study of dowel action in reinforced concrete beams. Magazine of Concrete Research, 51, no. 2, pp. 131-141. DOI: 10.1680/macr.1999.51.2.131.

[6] Carmona J.R., Ruiz G., Viso J.R. (2007). Mixed-mode crack propagation through reinforced concrete. Engineering Fracture Mechanics, 74, pp. 2788-2809. DOI: 10.1016/j.engfracmech.2007.01.004.

[7] Hamrat M., Boulekbache B., Chemrouk M., Amziane S. (2010). Shear behaviour of RC beams without stirrups made of normal strength and high strength concretes. Advances in Structural Engineering, 13, pp. 29-41.

[8] Carpinteri A., Carmona J.R., Ventura G. (2011). Failure Mode Transitions in Reinforced Concrete Beams - Part 2: Experimental Tests. ACI Structural Journal, 3, pp. 286-292. DOI: 10.1260/1369-4332.13.1.29.

[9] Caldentley A.P., Padilla P., Muttoni A., Ruiz M.F. (2012). Effect of Load Distribution and Variable Depth on Shear Resistance of Slender Beams without Stirrups. ACI Structural Journal, 5, pp. 595-603.

[10] Reineck K., Bentz E.C., Fitic B.,. Kuchma D.A, Bayrak O. (2013). ACI-DafStb database of shear tests on slender reinforced concrete beams without stirrups. ACI Structural Journal, 110 (5), pp. 867-876.

[11] EN 1992-1-1 (2004). Eurocode 2. Design of concrete structures - general rules and rules for buildings. CEN, Brussels.

[12] ACI 318-14, (2014). Building Code Requirements for Structural Concrete. American Concrete Institute, Farmington Hills, Michigan.

[13] Cavagnis F., Ruiz M. F., Muttoni A. (2015). Shear failures in reinforced concrete members without transverse reinforcement: An analysis of the critical shear crack development on the basis of test results. Engineering Structures, 103, pp. 157-173. DOI: $10.1016 /$ j.engstruct.2015.09.015.

[14] Tung N.D., Tue N.V. (2016). A new approach to shear design of slender reinforced concrete members without transverse reinforcement. Engineering Structures, 107, pp. 180-194. DOI: 10.1016/j.engstruct.2015.04.015.

[15] Tung N.D., Tue N.V. (2016). Effect of support conditions and loading arrangement on the shear response of reinforced concrete beams without transverse reinforcement. Engineering Structures, 111, pp. 370-382.

DOI: $10.1016 /$ j.engstruct.2015.12.022. 
[16] Avagnis F., Ruiz M.F., Muttoni A. (2018), A mechanical model for failures in shear of members without transverse reinforcement based on development of a critical shear crack. Engineering Structures, 157, pp. 300-315. DOI: 10.1016/j.engstruct.2017.12.004.

[17] Słowik M. (2019). The analysis of failure in concrete and reinforced concrete beams with different reinforcement ratio. Archive of Applied Mechanics, 89, pp. 885-895. DOI: 10.1007/s00419-018-1476-5.

[18] Vecchio F.J., Collins M.P. (1986). The Modified Compression Field Theory for Reinforced Concrete Elements Subjected to Shear. Journal of ACI, 83 (2), pp. 219-231.

[19] Muttoni A., Ruiz M.F. (2008). Shear Strength of Members without Transverse Reinforcement as Function of Critical Shear Crack Width. ACI Structural Journal, 105 (2), March-April, pp. 163-172.

[20] fib Model Code for Concrete Structures 2010, (2013). Ernst \& Sohn, Berlin.

[21] CSA Committee A23.3-14, (2014). Design of Concrete structures. Canadian Standards Association.

[22] SIA 262:2003, (2003). Concrete Structures. Code. Swiss Society of Engineers and Architects.

[23] Słowik M., Smarzewski P. (2012) Study of the scale effect on diagonal crack propagation in concrete beams. Computational Materials Science, 64, pp. 216-220. DOI: 10.1016/j.commatsci.2012.05.068.

[24] Hillerborg A., Modeer M., Petersson P.E. (1976). Analysis of crack formation and crack growth in concrete by means of fracture mechanics and finite elements. Cement and Concrete Research, 6, pp. 773-782.

[25] Walraven J.C. (1981). Fundamental analysis of aggregate interlock. Journal of the Structural Division, ASCE, 107 (ST11), pp. 2245-2270.

[26] Pundir M. at al. (2019). Review of fundamental assumptions of the Two-Phase model for aggregate interlocking in cracked concrete using numerical methods and experimental evidence. Cement and Concrete Research, $125,105855$. DOI: 10.1016/j.cemconres.2019.105855.

[27] Huber T., Huber P., Kollegger J. (2019). Influence of aggregate interlock on the shear resistance of reinforced concrete beams without stirrups. Engineering Structures, 186, pp. 26-42. DOI: 10.1016/j.engstruct.2019.01.074.

[28] Słowik M., Smarzewski P. (2014). Numerical modeling of diagonal cracks in concrete beams, Archive of Civil Engineering, 60 (3), pp. 307-322. DOI: 10.2478/ace-2014-0021.

[29] fib Bulletin 85: (2018). Towards a rational understanding of shear in beams and slabs. Technical Report, Fédération internationale du béton.

[30] Kaufmann W., Mata-Falcón J., Beck A. (2018) Future directions for research on shear in structural concrete. In: fib Bulletin 85: Towards a rational understanding of shear in beams and slabs. pp. 323-338. 